Empowerment: Jurnal Pengabdian Kepada Masyarakat Vol. 1, No. 2 Oktober 2021, Hal. 18 - 30

\title{
PEMANFAATAN MULTIMEDIA MENGGUNAKAN GOOGLE SITES BAGI GURU-GURU SMP SMK PUTRA SATRIA SEBAGAI MEDIA PEMBELAJARAN JARAK JAUH
}

\author{
Agus Suharto ${ }^{1}$, Jazuli Muchtar ${ }^{2}$, R Empu Cahyoari Yuwono ${ }^{3}$, Aditya Abdul Rachman ${ }^{4}$, Pascal \\ Yudistira $^{5}$, Laraswati ${ }^{6}$, Airima Fauziana ${ }^{7}$ \\ Universitas Pamulang \\ Program Studi Sistem Informasi Universitas Pamulang Tangerang Selatan \\ e-mail: dosen01539@unpam.ac.id”, jazulimuhtar2015@gmail.com²
}

\begin{abstract}
Teachers and staff in carrying out their duties cannot be separated from the use of information technology, in several schools including partner schools, namely SMP \& SMK PUTRA SATRIA. there are still many teachers and TU staff who are not familiar with the use of information technology. For this reason, it is necessary to increase skills through training in the use of Google application information system software. This activity is carried out in 3 stages, namely the preparation stage, then the Distance Learning training stage with Google Sites, Google Classroom, then the effectiveness evaluation stage with questionnaires by participants, Based on the data obtained from the questionnaire via google form about the effectiveness of distance learning using the Google Sites platform, google classroom, as follows very ineffective $7 \%$, ineffective $10 \%$, quite effective $10 \%$, effective $67 \%$, very effective $7 \%$
\end{abstract}

\section{Keywords: SMP \& SMK Putra Satria, Google Sites, Distance Learning,}

\begin{abstract}
ABSTRAK
Guru dan staf dalam melaksanakan tugasnya tidak lepas dari pemanfaatan teknologi informasi, dibeberapa sekolah termasuk di sekolah mitra, yaitu SMP \& SMK PUTRA SATRIA . masih banyak guru dan staff TU yang belum mengenal pemanfaatan teknologi informasi. Untuk itu dibutuhkan peningkatan keterampilan melalui pelatihan penggunaan perangkat lunak sistem informasi aplikasi google Kegiatan ini dilaksanakan dengan 3 tahap yaitu tahap persiapan, lalu tahap pelatihan Pembelajaran Jarak Jauh dengan Google Sites, Google Classroom selanjutnya tahap evaluasi efektifitas dengan kuesioner oleh peserta. Berdasarkan data yang diperoleh dari kuesioner melalui google form tentang Efektivtas Pembelajaran jarak jauh dengan menggunakan platform Google Sites, google classroom, sebagai berikut sangat tidak efektif $7 \%$, tidak efektif $10 \%$, cukup efektif $10 \%$, efektif $67 \%$, sangat efektif $7 \%$
\end{abstract}

Kata Kunci: SMP \& SMK Putra Satria, Google Sites, Pembelajaran Jarak Jauh,

\section{PENDAHULUAN}

Perkembangan Teknologi Informasi sangat cepat saat ini diperlukan sumberdaya manusia yang selalu mengikuti perkembangan teknologi informasi termasuk di sekolah dasar, karena guru dan staf dalam melaksanakan tugasnya tidak lepas dari pemanfaatan teknologi 
Empowerment: Jurnal Pengabdian Kepada Masyarakat Vol. 1, No. 2 Oktober 2021, Hal. 18 - 30 STAI Darul Kamal NW Kembang Kerang

informasi tersebut, misalnya seorang guru membuat bahan ajar dengan slide, membuat nilai mahasiswa dengan database memanfaatkan proyektor untuk menampilkan materi pembelajaran, memberikan pembelajaran secara daring. Sekolah harus berusaha memfasilitasi bagi guru dan staff TU agar pada saat melaksanakan tugasnya dan tujuan pembelajarannya bisa tercapai.

Seharusnya perangkat Teknologi Informasi dan Komunikasi (TIK) dapat dimanfaatkan lebih jauh untuk meningkatkan kualitas pembelajaran di ruang kelas dengan cara mengintegrasikannya ke dalam kurikulum yang ada. Penggunaan teknologi berbeda dengan maksud dari Integrasi Teknologi. Kegiatan mengajarkan penggunaan teknologi seperti kegiatan diatas, sangat berbeda dengan kegiatan Integrasi Teknologi dalam kegiatan pembelajaran. Integrasi teknologi adalah penggunaan teknologi informasi dan komunikasi dalam wilayah konten secara umum dalam pendidikan untuk memungkinkan mereka belajar keterampilan komputer dan teknologi. Secara umum, kurikulumlah yang mengendalikan penggunaan teknologi bukan sebaliknya '. Sekaranglah saatnya para guru berfikir bagaimana teknologi dapat membantu mereka, khususnya dalam pemanfaatannya untuk mendukung pembelajaran yang aktif, kreatif, efektif dan menyenangkan (PAKEM) di dalam kelas ${ }^{2}$. Dalam integrasi teknologi informasi dalam ruang kelas, teknologi informasi harus diposisikan sebagai "alat" yang mampu membantu/menolong guru secar ${ }^{3} a$ efektif dalam mencapai tujuan pembelajaran.

Masih banyaknya guru dan staff TU yang belum mengenal pemanfaatan teknologi informasi tersebut, dikebanyakan sekolah juga terjadi di sekolah mitra, yaitu SMP \& SMK PUTRA SATRIA Ciledug Tangerang Selatan. Untuk meningkatkan mutu pengetahuan serta keterampilan pada Siswa, guru dan staff TU disekolah SMP \& SMK PUTRA SATRIA Ciledug, dibutuhkan peningkatan keterampilan melalui pelatihan penggunaan perangkat lunak serta perawatan perangkat Teknologi Informasi. Manfaat yang akan didapat oleh peserta melalui kegiatan pengabdian masyarakat ini bagi guru dan staff TU dalam rangka melaksanakan tugas pembelajaran serta pelaporan tidak mengalami banyak kendala serta mampu mengatasi masalah-masalah berkaitan dengan teknologi informasi. Dengan demikian kegiatan ini juga membantu sekolah untuk meningkatkan proses pembelajaran serta dalam memberikan pelaporan baik ke dinas pendidikan dasar dan menengah atau kepada stakeholder Selain itu mutu pemanfaatan teknologi informasi akan semakin mendorong kualitas total dari manajemen sekolah. Dengan Permasalahan yang ada maka kami ajukan usulan program pengabdian masyarakat mengoptimalkan pemanfaatan google sites bagi guru guru sebagai media pembelajaran jarak jauh pada SMP \& SMK Putra Satria

\footnotetext{
1 Mohammad badru Tamam “Implementasi Model Belajar Kolaboratif Kelas Digital di Sekolah Tinggi IImu Tarbiyah Raden Wijaya Mojokerto “,PROGRESSA Journal of Islamic Religious Instruction Vol. 2 No. 1 Pebruari (2018)

2 Pemanfaatan TIK VS Integrasi TIK Dalam Pembelajaran,(2021), from https://edukasi101.com/pemanfaatan-tikvs-integrasi-tik-dalam-pembelajaran/
} 
Empowerment: Jurnal Pengabdian Kepada Masyarakat Vol. 1, No. 2 Oktober 2021, Hal. 18 - 30 STAI Darul Kamal NW Kembang Kerang

Ciledug Jakarta selatan sebagai solusinya.

\section{METODE}

SMP \& SMK PUTRA SATRIA Ciledug Tangerang Selatan beralamat Jl. Ciledug Raya No 46, Petukangan Utara, Kec. Pesanggrahan, Jakarta Selatan No. Telpon : 0215853945 no NPSN : 20102465 dengan Akreditasi peringkat $B^{3}$

Kompetensi Keahlian / Jurusan SMK Putra Satria Jakarta Selatan yaitu :

1. Bisnis Daring dan Pemasaran

2. Otomatisasi dan Tata Kelola Perkantoran

3. Teknik Komputer dan Jaringan

Pada Kegiatan PKM ini sendiri pesertanya adalah para guru dan tenaga pendidikan dari Yayasan Pendidikan Putra Satria baik yang sudah mengetahui tentang Google Sites sebelumnya maupun yang belum mengetahui. Jumlah rekapitulasi data pokok SDM nya adalah sebagai berikut :

Tabel 1

PD SMK Putra

\begin{tabular}{|l|l|l|l|l|}
\hline \multicolumn{5}{|l|}{ Data PTK dan PD } \\
\hline Uraian & Guru & Tendik & PTK & PD \\
\hline Laki-laki & 10 & 3 & 13 & 200 \\
\hline Perempuan & 12 & 4 & 16 & 114 \\
\hline Total & 22 & 7 & 29 & 314 \\
\hline
\end{tabular}

data PTK dan

Satria

Metode yang digunakan diuraikan sebagai berikut :

\section{Observasi}

Metode observasi dilakukan untuk mendapatkan persetujuan mitra, informasi mengenai keadaan sarana dan prasarana, serta para guru dalam pemanfaatan terhadap teknologi informasi di SMP \& SMK PUTRA SATRIA Ciledug Melalui metode ini diperoleh data berupa keadaan sekolah, infrastruktur teknologi informasi, serta permasalahanpermasalahan lainnya mengenai pemanfaatan teknologi informasi di sekolah.

\section{Diskusi}

Diskusi dilakukan untuk membahas mengenai solusi dari permasalahan-permasalahan yang muncul mengenai pemanfaatan teknologi informasi. Diskusi ini terjadi antara Tim

\footnotetext{
${ }^{3}$ Sekolah Kita, (20102465) SMK PUTRA SATRIA 2021 from

https://sekolah.data.kemdikbud.go.id/index.php/chome/profil/3f8a702b-b929-4012-b7fb-8e44fab0055e
} 
Empowerment: Jurnal Pengabdian Kepada Masyarakat Vol. 1, No. 2 Oktober 2021, Hal. 18 - 30 STAI Darul Kamal NW Kembang Kerang

Pengusul dengan mitra kegiatan, yaitu Kepala Sekolah dan guru SMP \& SMK PUTRA SATRIA Ciledug Harapan diskusi ini diperoleh solusi untuk permasalahan mengenai pemanfaatan teknologi informasi yaitu melalui "Peningkatan Keterampilan dan Pemanfaatan Teknologi Informasi Guru dan Staff pada SMP \& SMK PUTRA SATRIA Ciledug

\section{Dokumentasi}

Dokumentasi dalam kegiatan ini dilakukan untuk memperoleh data-data fisik yang berhubungan dengan keadaan infrastruktur dan pemanfaatan teknologi informasi yang terdapat di sekolah seperti jaringan Internet, perangkat WIFI, printer dan LCD proyektor serta beberapa komputer.

\section{Pelatihan Keterampilan}

Metode Pelatihan Keterampilan merupakan metode inti dari kegiatan ini. Metode ini dilaksanakan di sekolah pelatihan Membuat Website dengan Google Site, Google class Room, Google Form, Google Calender, Google Drive.

\section{Evaluasi}

Hasil Evaluasi kuesioner mengenai efektivitas pembelajaran daring yang dilakukan setelah pelatihan dilakukan dengan responden para peserta pelatihan sebanyak 30 guru dan dan tendik SMK Putra Satria Cilediug untuk mendapatkan persepsi.

\section{HASIL DAN PEMBAHASAN}

Pelaksanaan pengabdian masyarakat ini dilakukan dalam tiga tahap, yakni tahap persiapan, tahap Pelatihan, dan tahap evaluasi persepsi guru terhadap efisiensi pembelajaran jarak jauh menggunakan google sites, sebagai berikut.

\section{Tahap persiapan}

Dalam tahap ini penulis melakukan observasi di lokasi penelitian yakni di SMK Putra Satria . Hasil pertemuan awal dengan Kepala Sekolah, diputuskan bahwa persoalan prioritas yang disepakati untuk diselesaikan selama pelaksanaan program Pengabdian adalah mengenai upaya meningkatkan keterampilan bagi para guru dan staff TU. Justifikasi Tim Pengusul bersama mitra dalam hal ini adalah keterbatasan kemampuan (sumber daya manusia, latar belakang pendidikan), Kegiatan yang relatif mampu dilakukan secara swadaya antara Tim Pengusul dan mitra adalah meningkatkan pengetahuan dan keterampilan bagi guru dan staff TU.

Berikut ini adalah kerangka desain pemecahan masalah yang kami buat dalam melaksanakan Kegiatan PKM di Yayasan Putra Satria :

1. Pembukaan pelatihan dengan judul "Mengoptimalkan Pemanfaatan Multimedia Menggunakan Google Sites Bagi Guru-Guru SMP \& SMK Putra Satria Sebagai 
Empowerment: Jurnal Pengabdian Kepada Masyarakat Vol. 1, No. 2 Oktober 2021, Hal. 18 - 30 STAI Darul Kamal NW Kembang Kerang

Media Pembelajaran Jarak Jauh ".

2. Memberikan penjelasan serta materi yang berkaitan dengan judul.

3. Praktek pembuatan Google Sites yang akan dilakukan peserta.

4. Memberikan bantuan jika dalam praktek ada peserta yang mengalami kesulitan.

5. Memberikan kuesioner persepsi efisiensi pembelajaran jarak jauh dengan google form.

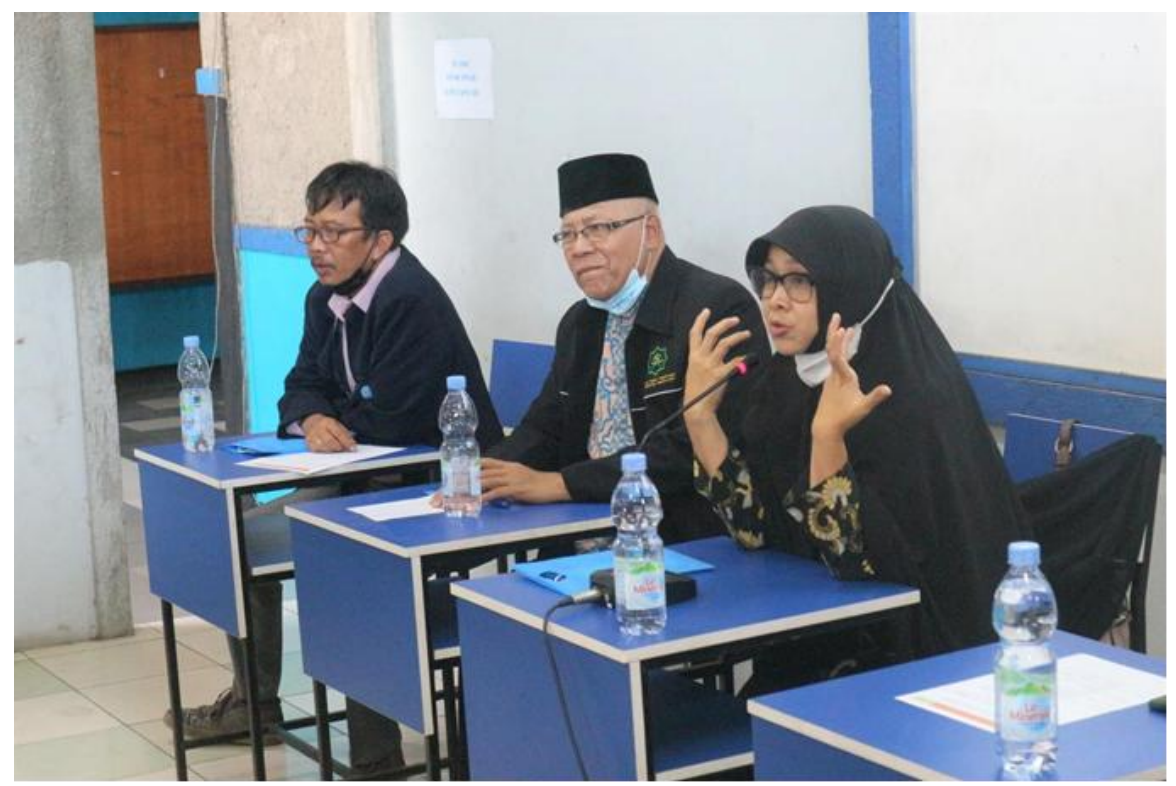

Gambar 1. Diskusi kerangka desain pemecahan dalam melaksanakan Kegiatan Pengabdian kepada masyarakat

\section{Tahap Pelaksanaan Pelatihan}

Untuk kegiatan PKM yang dilaksanakan yaitu hari pada Selasa - rabu 6-7 April 2021 yang dimulai pada pukul 08.00 s/d 15.00, jumlah peserta yang akan melakukan pelatihan ini berkisar 30 orang, yang nantinya akan dibagi 2 ruangan dengan masingmasing ruangan berisi 15 peserta. Ruangan I akan memberikan pelatihan tentang Google Sites serta melakukan praktek dalam pembuatannya. Sedangkan untuk Ruangan II kami akan memberikan pelatihan tentang Google Form dan Google Sheet sebagai aplikasi pendukung untuk menggunakan Google Sites nantinya.

Berikut ini adalah susunan acara yang kami buat dalam kegiatan PKM ini untuk membantu mengatur jalannya kegiatan yang kami akan lakukan :

Tabel 2 Jadwal dan Waktu Pelaksanaan Pengabdian Kepada Masyarakat

\begin{tabular}{|l|l|l|l|}
\hline WAKTU & RUANG & ACARA & KETERANGAN \\
\hline
\end{tabular}


Empowerment: Jurnal Pengabdian Kepada Masyarakat Vol. 1, No. 2 Oktober 2021, Hal. 18 - 30 STAI Darul Kamal NW Kembang Kerang

\begin{tabular}{|c|c|c|c|}
\hline $07.30-08.00$ & & Pengisian Daftar Hadir & \\
\hline $08.00-09.00$ & & $\begin{array}{ll}\text { 1. } & \text { Pembukaan dan } \\
& \text { Pengarahan oleh } \\
\text { Kepala Sekolah } \\
\text { SMK } \\
\text { 2. Sambutan Ketua } \\
\text { YPPS } \\
\text { 3. Sambutan } \\
\text { Pembimbing } \\
\text { Kegiatan } \\
\text { Pengabdian } \\
\text { Kepada Masyarakat } \\
\text { (PKM) }\end{array}$ & $\begin{array}{l}\text { Risyda Zulfiani, S.E } \\
\text { Desi Ariyanti } \\
\text { Ir. Agus Suharto, M.Kom }\end{array}$ \\
\hline $09.00-12.00$ & Ruang I & $\begin{array}{l}\text { 4. Google Sites Sesi I } \\
\text { (Quiz, Pengenalan } \\
\text { materi dan Praktek) }\end{array}$ & $\begin{array}{l}\text { Ir. Agus Suharto, M.Kom } \\
\text { (Dosen) }\end{array}$ \\
\hline $09.00-12.00$ & Ruang II & $\begin{array}{l}\text { 5. Google Form dan } \\
\text { Google Sheet Sesi } \\
\text { (Pengenalan) } \\
\text { materi, quiz, dan } \\
\text { praktek }\end{array}$ & $\begin{array}{l}\text { Aditya Abdul Rachman } \\
\text { (Mahasiswa) }\end{array}$ \\
\hline $12.00-13.00$ & & Ishoma & \\
\hline $13.00-15.00$ & Ruang I & $\begin{array}{ll}\text { 6. } & \text { Google Sites Sesi II } \\
\text { 7. } & \text { quiz dan } \\
\text { pembuatan materi } \\
\text { di google sites } \\
\text { pembelajaran } \\
\text { berdasarkan materi } \\
\text { yang di ampu) }\end{array}$ & $\begin{array}{l}\text { R Empu Cahyoari Y } \\
\text { (Mahasiswa) } \\
\text { Fergi Pradika } \\
\text { (Mahasiswa) }\end{array}$ \\
\hline $13.00-15.00$ & Ruang II & $\begin{array}{l}\text { 8. Google Form dan } \\
\text { Google Sheets Sesi } \\
\text { II } \\
\text { 9. Materi lanjutan, } \\
\text { quiz, dan praktek } \\
\text { penggunaan }\end{array}$ & $\begin{array}{l}\text { Aditya Abdul Rachman } \\
\text { (Mahasiswa) } \\
\text { R Empu Cahyoari Y } \\
\text { (Mahasiswa) }\end{array}$ \\
\hline
\end{tabular}


Empowerment: Jurnal Pengabdian Kepada Masyarakat Vol. 1, No. 2 Oktober 2021, Hal. 18 - 30 STAI Darul Kamal NW Kembang Kerang

\begin{tabular}{|l|l|l|l|}
\hline 15.00 & $\begin{array}{l}\text { 10. Evaluasi Kegiatan } \\
\text { PKM dengan } \\
\text { kuesioner }\end{array}$ & Panitia \\
& & \\
\hline
\end{tabular}

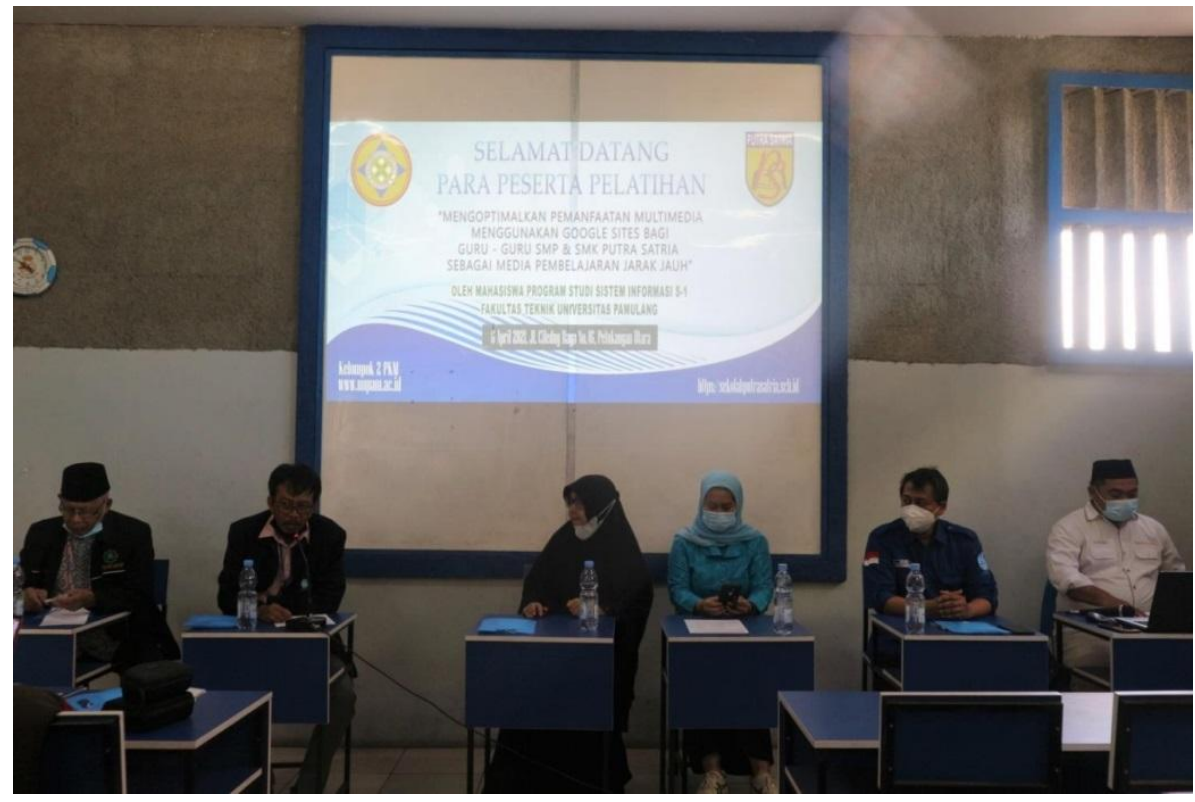

Gambar 2 . Pembukaan Kegiatan Pengabdian kepada masyarakat

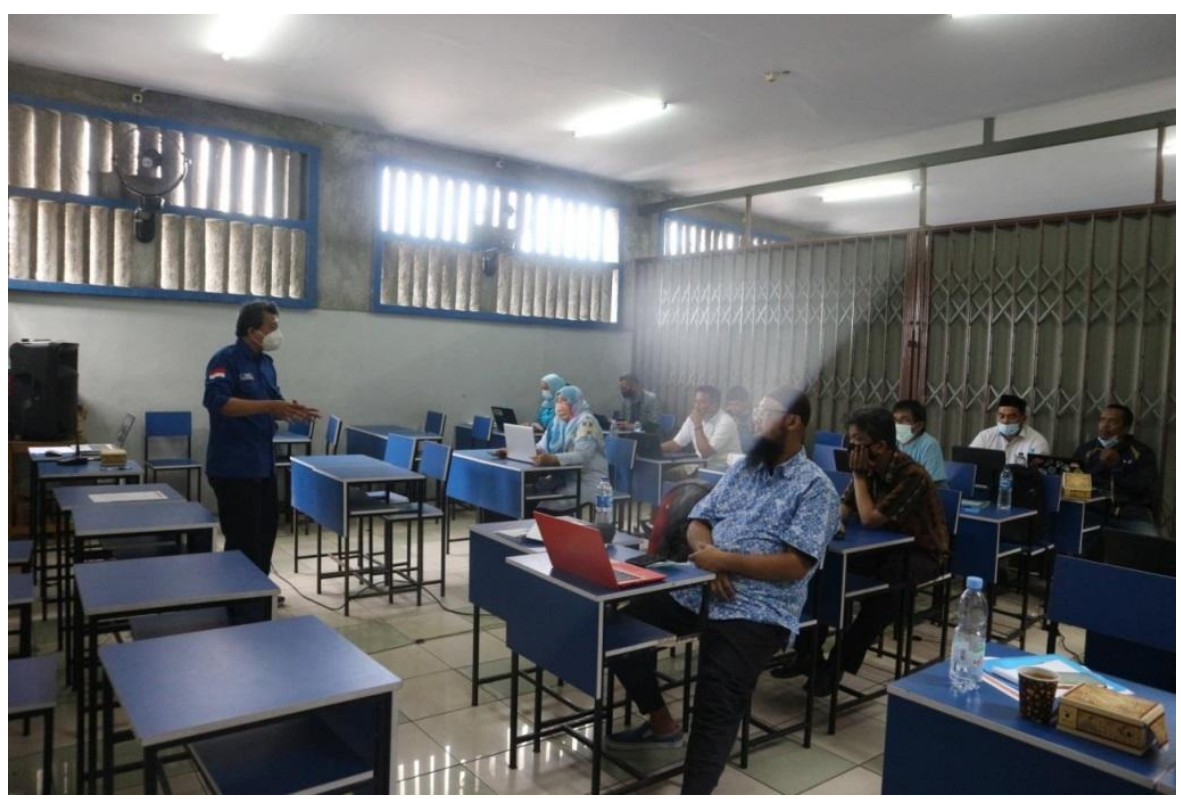


Empowerment: Jurnal Pengabdian Kepada Masyarakat Vol. 1, No. 2 Oktober 2021, Hal. 18 - 30 STAI Darul Kamal NW Kembang Kerang

Gambar 3 . Pelaksanaan Kegiatan Pengabdian kepada masyarakat ruang I

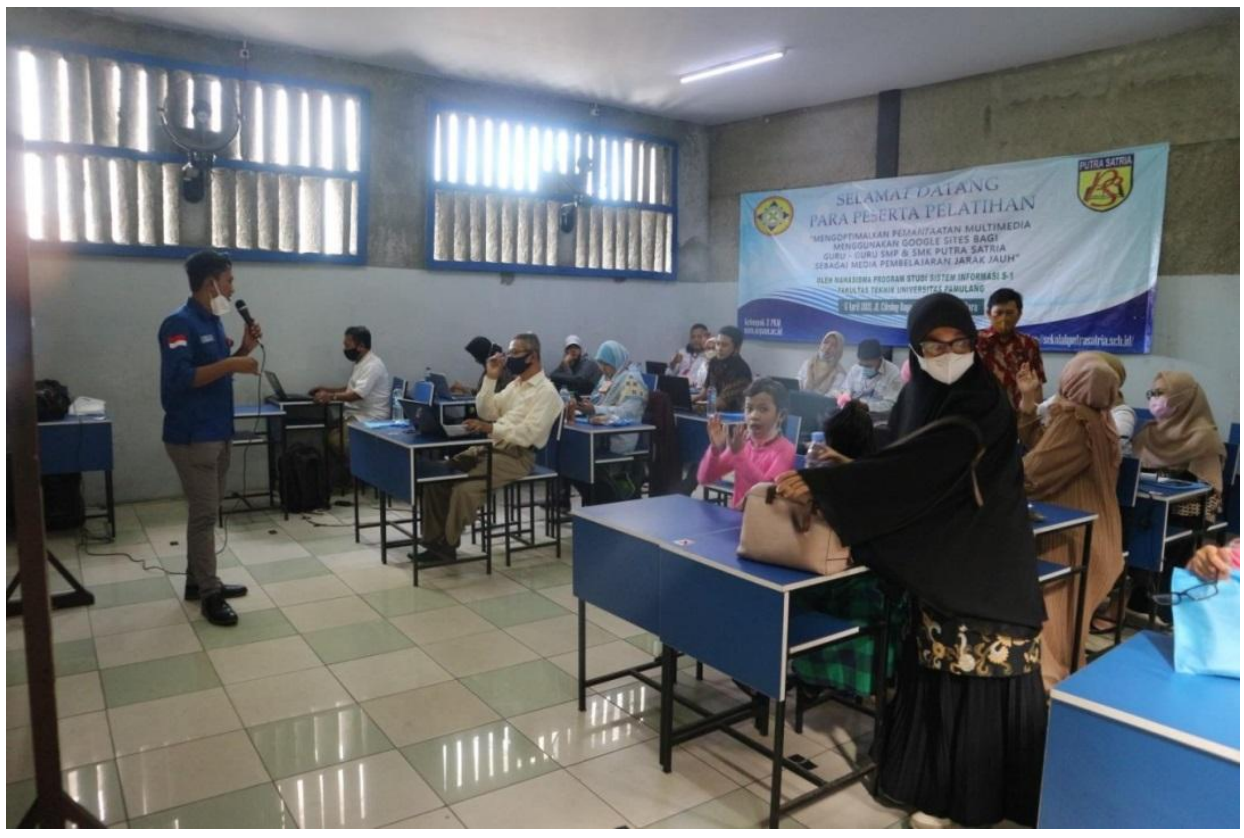

Gambar 4 . Pelaksanaan Kegiatan Pengabdian kepada masyarakat ruang II

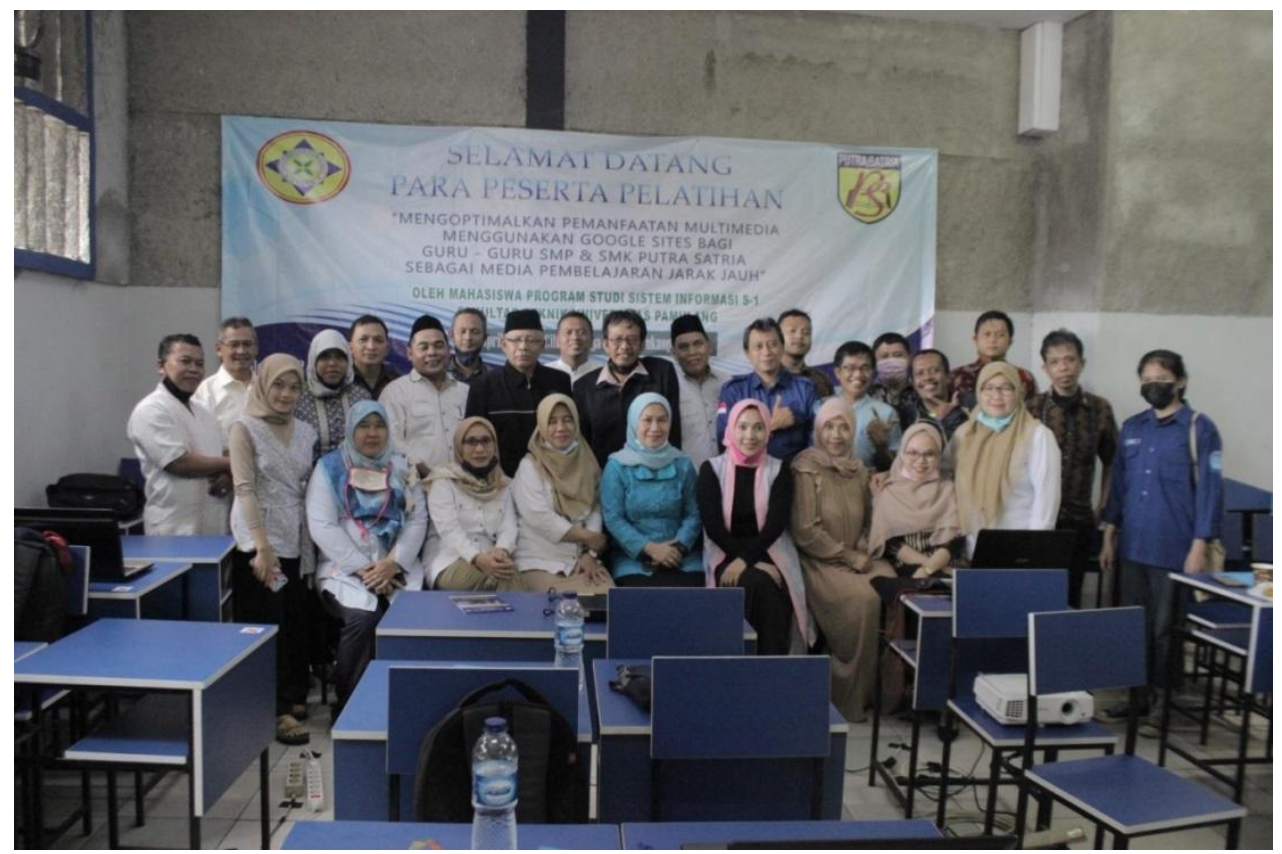

Gambar 5. Foto bersama peserta guru guru dan tim Kegiatan Pengabdian kepada masyarakat 
Empowerment: Jurnal Pengabdian Kepada Masyarakat Vol. 1, No. 2 Oktober 2021, Hal. 18 - 30 STAI Darul Kamal NW Kembang Kerang

\section{Tahap Evaluasi Pelatihan oleh Peserta Guru guru SMK Putra Satria}

Tahap evaluasi ini adalah dilakukan oleh peserta para guru yang akan menerapkan sistem pembelajaran jarak jauh menggunakan google sites. Sampel penelitian ini adalah guru guru SMK Putra Satria sebanyak 30 orang yang telah mengikuti pelatihan tersebut. Dalam kuseioner ini hanya mengukur apakah efektif atau tidak pembelajaran jarak jauh berikut hasil tabelnya adalah :

Tabel 3 Hasil kuesioner

\begin{tabular}{|l|r|c|}
\hline Kategori & Hasil & Presentase \\
\hline Sangat tidak efektif & 2 & $7 \%$ \\
\hline Tidak efektif & 3 & $10 \%$ \\
\hline Cukup efektif & 3 & $10 \%$ \\
\hline Efektif & 20 & $67 \%$ \\
\hline Sangat efektif & 2 & $7 \%$ \\
\hline
\end{tabular}

Berdasarkan hasil kuesinoner tersebut dilakukan pula analisis persentase dengan infografis ${ }^{4}$ hasilnya adalah sebagai berikut :

47 Langkah Cara Membuat Infografis dari A-Z, 2021 from https://www.niagahoster.co.id/blog/caramembuat-infografis/?amp\#Apa_itu_Infografis 
Empowerment: Jurnal Pengabdian Kepada Masyarakat Vol. 1, No. 2 Oktober 2021, Hal. 18 - 30 STAI Darul Kamal NW Kembang Kerang

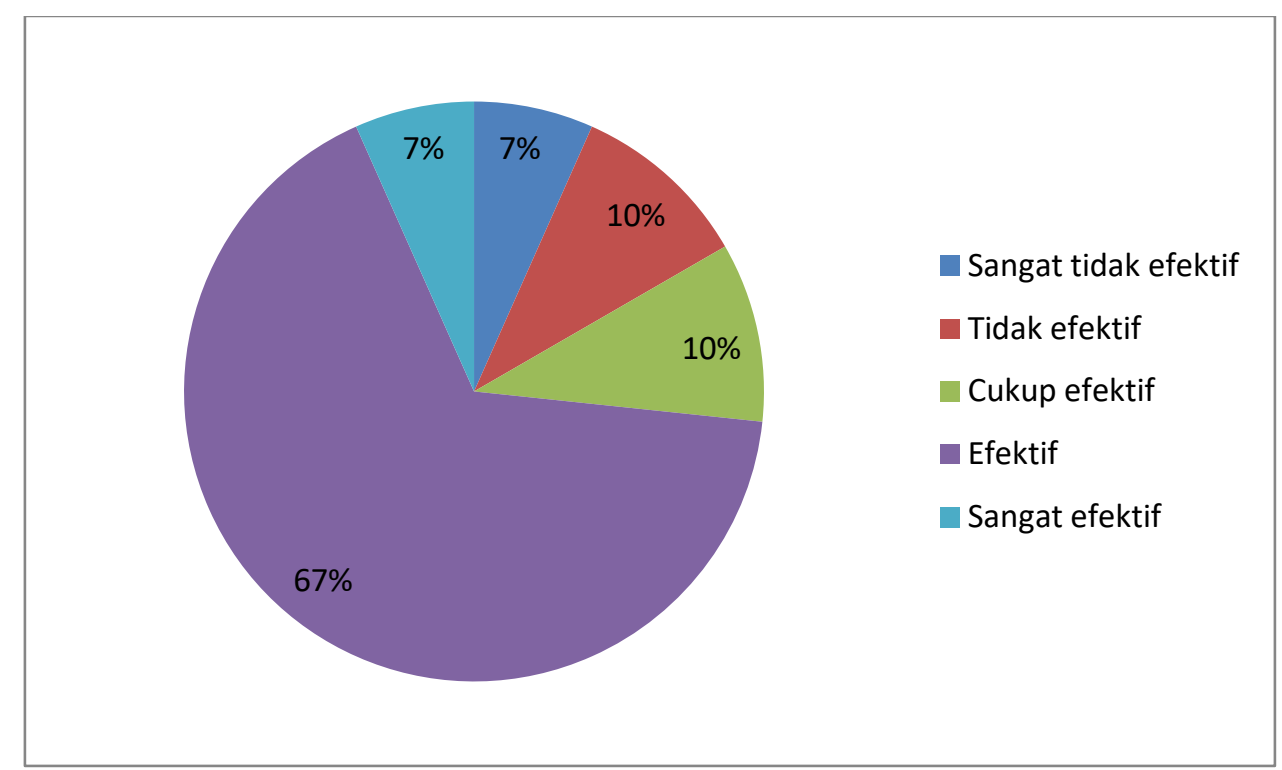

Gambar 6. InfoGrafis hasil kuesioner Pembelajaran Jarak Jauh menggunakan Google Sites

\section{KESIMPULAN}

Berdasarkan kegiatan PKM yang telah kami laksanakan di Yayasan Putra Satria yang beralamat di Jl. Ciledug Raya No.46, Petukangan Utara, Pesanggrahan, Jakarta Selatan dapat disimpulkan bahwa :

1. Materi yang disampaikan terkait dengan tema "Mengoptimalkan Pemanfaataan Multimedia Menggunakan Google Sites dapat dipahami dan di implementasikan oleh guru-guru yang berada di lingkungan Yayasan Putra Satria.

2. Hasil Evaluasi pengabdian masyarakat oleh guru guru SMP-SMK Putra Satria Ciledug secara daring /jarak jauh menggunakan Google sites sebagai media pembelajarannya adalah Sangat tidak efektif $7 \%$, Tidak efektif $10 \%$, Cukup efektif $10 \%$, Efektif $67 \%$, Sangat efektif $7 \%$ dan dapat diputuskan untuk proses belajar mengajar selanjutnya dapat di gunakan.

\section{UCAPAN TERIMA KASIH}

Puji syukur Alhamdulillah kehadirat Allah SWT yang telah melimpahkan segala rahmat dan karunia-Nya, sehingga penulis dapat menyelesaikan laporan akhir program pengabdian kepada masyarakat (PKM) yang berjudul "Mengoptimalkan Pemanfaatan Multimedia 
Empowerment: Jurnal Pengabdian Kepada Masyarakat Vol. 1, No. 2 Oktober 2021, Hal. 18 - 30 STAI Darul Kamal NW Kembang Kerang

Menggunakan Google Sites Bagi Guru-Guru SMK Putra Satria Sebagai Media Pembelajaran Jarak Jauh". Penulis dengan segala kerendahan hati menyampaikan ucapan terima kasih kepada :

1. Bapak Dr (HC) Drs.H Darsono,selaku ketua yayasan Sasmita Djaya Group.

2. Bapak Dr. E. Nurzaman AM., M.M., M.Si Selaku Rektor Universitas Pamulang.

3. Bapak Dr. Ali Maddinsyah, S.E, M.M, selaku Ketua LPPM Universitas Pamulang.

4. Bapak Dede Supriyadi, S.Kom, M.Kom, selaku Ketua Program Studi Sistem Informasi.

5. Ibu Desi Ariyanti selaku ketua yayasan Putra Satria Ciledug Jakarta

6. Ibu Risyda Zulfiani, S.E selaku kepala sekolah SMK Putra Satria Jakarta

7. Teman teman mahasiswa program studi Sistem Informasi yang telah berpartisipasi dalam kegiatan Pengabdian kepada masyarakat

Semoga Allah SWT membalas kebaikan dan selalu mencurahkan hidayah serta taufik-Nya kepada kita semua, Aamiin.

\section{DAFTAR PUSTAKA}

P.P Diemas, Rina Harimurti "Pengaruh Penerapan Tools Google Clasroom Pada Model Pembelajaran Project Based Learning Terhadap Hasil Belajar Siswa." Jurnal IT-Edu Vol 2(1),pp 59-67, 2017.

Mohammad badru Tamam "Implementasi Model Belajar Kolaboratif Kelas Digital di Sekolah Tinggi Ilmu Tarbiyah Raden Wijaya Mojokerto ",PROGRESSA Journal of Islamic Religious Instruction Vol. 2 No. 1 Pebruari, pp 95-102, 2018

Maharani, N., \& Kartini, K. S., "Penggunaan google classroom sebagai pengembangan kelas virtual dalam keterampilan pemecahan masalah topik kinematika pada mahasiswa jurusan sistem komputer", PENDIPA Journal of Science Education, Vol 3, No 3 ,pp167173. (2019)

Mustakim. "Efektivitas Pembelajaran Daring Menggunakan Media Online Selama Pandemi Covid-19 pada Mata Pelajaran Matematika", . Journal Of Islamic Education, Vol 3 No 1 , (2020).

M Herlinda. "Efektivitas Pembelajaran Daring Menggunakan Media Online Selama Pandemi Covid-19 pada Mata Pelajaran Matematika", . Journal Of Islamic Education, Vol 3 No 1 , (2020)

\section{Sumber Internet}

Pemanfaatan TIK VS Integrasi TIK Dalam Pembelajaran,(2021), from https://edukasi101.com/pemanfaatan-tik-vs-integrasi-tik-dalam-pembelajaran/ 
Empowerment: Jurnal Pengabdian Kepada Masyarakat Vol. 1, No. 2 Oktober 2021, Hal. 18 - 30 STAI Darul Kamal NW Kembang Kerang

Sekolah Kita, (20102465) SMK PUTRA SATRIA 2021 from https://sekolah.data.kemdikbud.go.id/index.php/chome/profil/3f8a702b-b929-4012-b7fb$\underline{8 \mathrm{e} 44 \mathrm{fab0055e}}$

7 Langkah Cara Membuat Infografis dari A-Z, 2021 from https://www.niagahoster.co.id/blog/cara-membuat-infografis/?amp\#Apa itu Infografis 